\title{
Model Pengelolaan Air Bersih di Kecamatan Pamulang, Kota Tangerang Selatan
}

\section{Model of Water Management in Pamulang Sub-District, South Tangerang}

\author{
Alfonsus H. Harianja \\ Pusat Penelitian dan Pengembangan Kualitas dan Laboratorium Lingkungan (P3KLL), Badan Litbang dan \\ Inovasi (BLI), Kementerian Lingkungan Hidup dan Kehutanan (KLHK) \\ Kawasan PUSPIPTEK Gedung 210, Serpong, Tangerang Selatan 15310, e-mail: alfonsus88hrj@gmail.com
}

Diterima 15 September 2020, direvisi 23 September 2020, disetujui tanggal 19 Oktober 2020

\begin{abstract}
ABSTRAK
Model Pengelolaan Air Bersih di Kecamatan Pamulang, Kota Tangerang Selatan. Kelangkaan sumberdaya air untuk memenuhi kebutuhan penduduk memerlukan sistem pengelolaan yang baik, dengan memanfaatkan sumberdaya yang tersedia. Penelitian ini dilakukan untuk membuat model pengelolaan sumberdaya air bersih di Kecamatan Pamulang, Kota Tangerang Selatan dengan menggunakan metode pemodelan system dinamics. Data yang digunakan adalah data sekunder yang bersumber dari dokumen berupa laporan, hasil penelitian dan data dari Biro Pusat Statistik (BPS) yang terkait dengan kependudukan dan potensi sumberdaya air bersih pada kecamatan tersebut. Hasil pemodelan menunjukkan bahwa penyediaan air bersih yang hanya mengandalkan sumber air tanah tidak mencukupi kebutuhan penduduk pada tahun 2019. Rencana pemenuhan kebutuhan dengan penyediaan air oleh Perusahaan Daerah Air Minum (PDAM) dengan memanfaatkan air permukaan mulai tahun 2018 cukup membantu ketersediaan air bersih, namun kemudian mengalami defisit kembali pada tahun 2021. Skenario penggunaan kembali grey water merupakan alternatif pengelolaan air bersih yang lestari yang dibuktikan oleh surplus air bersih sampai tahun 2023.
\end{abstract}

Kata kunci: Air bersih, grey water, pemodelan, system dinamics, Tangerang Selatan.

\section{ABSTRACT}

Model of Water Management in Pamulang Sub-District, South Tangerang. The growing urban population requires a good water resource management system utilizing available sources. This research was conducted to provide a water resource management model in Pamulang Sub-District, South Tangerang Municipal employing system dynamics. Data used was secondary data such as related reports, research results, and annual statistics provided by Biro Pusat Statistik (BPS). The modeling results show that the business as usual system that relies solely on groundwater sources will not be sufficient in 2019. The local government plan to increase water supply by Perusahaan Daerah Air Minum (PDAM) starting in 2018 at first is adequate to raise the availability of clean water, although it lasts up to 2020. Grey water reuse scenario is an alternative in providing sustainable water sources, as evidenced by a surplus of clean water up to 2023.

Keywords: Clean water, grey water, modeling, South Tangerang, system dynamics. 


\section{Pendahuluan}

Sumberdaya air berperan sangat penting dalam pembangunan kependudukan, sosial dan ekonomi. Kota-kota besar menghadapi masalah polusi air karena pengaruh urbanisasi, pertumbuhan populasi dan perkembangan ekonomi (Irawan et al., 2014; Luo et al., 2019; Máñez et al., 2012) Peningkatan jumlah penduduk mengakibatkan peningkatan jumlah permintaan akan sumberdaya air (Berhanu et al., 2017), yang jika tidak dikelola dengan baik dapat mengakibatkan kelangkaan (Sun et al., 2017; Wang et al., 2016). Pada kenyataannya, sebagian penduduk dunia belum dapat mengakses air, sehingga tujuan tersebut dijadikan salah satu tujuan dalam target Sustainable Development Goals (SDG's) (Cronin et al., 2017; Fuchs et al., 2015), yakni penyediaan sarana dan prasarana air bersih untuk dapat menjangkau minimal $80 \%$ penduduk pada tahun 2025 (Dinas Tata Kota Bangunan dan Pemukiman Kota Tangerang Selatan, 2014; Sesestyo \& Laxmi, 2017; Wibowo \& Alfen, 2015).

Demikian juga permasalahan yang dihadapi oleh Kecamatan Pamulang, yang merupakan ibukota Kota Tangerang Selatan. Penyediaan air bersih belum mencukupi untuk memenuhi kebutuhan penduduk, yang disebabkan oleh kekurangan sarana penyedia air bersih, baik yang melalui jaringan perpipaan maupun yang tidak. Sampai dengan tahun 2017, sarana air bersih yang digunakan oleh masyarakat di Kecamatan Pamulang hanya sarana sumur gali, baik yang menggunakan pompa mesin maupun pompa manual. Walaupun kualitas air tanah termasuk bagus, namun sumber tersebut tidak dapat menjadi satu-satunya andalan (Rasulung et al., 2017), karena ketersediaan yang akan menghadapi kelangkaan serta dampak terhadap lingkungan yang besar (Zhu \& Chang, 2020). Pasokan air dari Perusahaan Daerah Air Minum (PDAM) belum tersedia, sama seperti beberapa daerah perkotaan lain di Indonesia (Ari et al., 2013; Nohong, 2018).

Berdasarkan data kependudukan dari Badan Pusat Statistik Kota Tangerang Selatan tahun 2015-2019, pertumbuhan penduduk di Kota Tangerang Selatan tercatat sebesar $3,6 \%$ per tahun, dengan jumlah penduduk pada tahun 2014 sampai dengan 2018 seperti pada Tabel 1 Survei yang dilakukan oleh Dinas Tata Kota dan Bangunan pada tahun 2013 menggambarkan bahwa kebutuhan air bersih penduduk di Pamulang adalah ratarata sebesar 148 liter per orang per hari, yang lebih tinggi daripada standar kebutuhan penduduk kota berukuran sedang (Ester Suoth, 2018; Rachmawati, 2012).

Permasalahan yang dianalisis dalam pemodelan ini adalah bagaimana model pengelolaan penyediaan air bersih di Kecamatan Pamulang untuk memenuhi kebutuhan pertumbuhan penduduk dengan memanfaatkan potensi air tanah, air baku PDAM dan air daur ulang (grey water).

Tabel 1. Penduduk dan Kebutuhan Air di Kecamatan Pamulang

\begin{tabular}{cccc}
\hline No. & Tahun & Jumlah Penduduk (orang)* $^{*}$ & Pemakaian Air (liter/tahun)** $^{*}$ \\
\hline 1 & 2014 & 323.951 & 21.874 .791 .275 \\
2 & 2015 & 332.984 & 22.484 .744 .600 \\
3 & 2016 & 341.968 & 23.091 .389 .200 \\
4 & 2017 & 350.923 & 23.696 .075 .575 \\
5 & 2018 & 359.810 & 24.296 .170 .250 \\
\hline
\end{tabular}

Sumber: * BPS Kabupaten Tangerang Selatan (Kecamatan Pamulang Dalam Angka 2015,2016, 2017,2018 dan 2019).

** (Dinas Tata Kota Bangunan dan Pemukiman Kota Tangerang Selatan, 2014) 
Skenario yang dilakukan adalah pemenuhan kebutuhan air penduduk perkotaan sebesar minimal $80 \%$ (sesuai tujuan SDGs), dengan memanfaatkan potensi air tanah, air baku PDAM, dan pemanfaatan air daur ulang (grey water). Potensi air tanah dan air baku untuk PDAM telah direncanakan oleh Dinas Tata Kota Bangunan dan Pemukiman Kota Tangerang Selatan, yang pada tahun 2014 direncanakan mulai beroperasi pada tahun 2018. Data pada tahun 2014 digunakan sebagai basis data referensi dalam pemodelan.

\section{Metodologi}

Penelitian menggunakan model System Dynamics dalam pemodelan pengelolaan air bersih di Kecamatan Pamulang. System Dynamics merupakan metode ilmiah yang menggabungkan analisis berbasis aplikasi komputer dan teori (Sun et al., 2017). Metode tersebut dapat digunakan untuk memperkirakan perilaku dan struktur serta umpan balik subsistem secara sistematis. Metode ini juga telah digunakan oleh peneliti-peneliti sebelumnya untuk memodelkan pengelolaan air baik dari aspek kuantitas (Nozari \& Liaghat, 2014; Sun et al., 2017) maupun kualitas (Hassanzadeh et al., 2019; Liu et al., 2015; Lukman et al., 2019; Wang et al., 2016). Tujuan pemodelan yang dilakukan pada umumnya adalah untuk mendapatkan model pengelolaan sumberdaya air yang lestari (Primadian N et al., 2016; Tian et al., 2020).

Penelitian menggunakan data referensi kependudukan, kebutuhan air, dan potensi air di Kecamatan Pamulang, serta data sekunder berupa laporan statistik dari Badan Pusat Statistik dan Dinas Tata Kota Bangunan dan Pemukiman Kota Tangerang Selatan. Demikian juga data asumsi, menggunakan data sekunder dari instansi dan hasil penelitian terkait sebelumnya.

Tahapan pemodelan dilakukan dengan mengadaptasi metode pemodelan system dynamics, seperti dilakukan beberapa penelitian terdahulu (Rasekh \& Brumbelow, 2015; Sun et al., 2017; Wei et al., 2016) dengan tahapan seperti pada Gambar 1 .

Tahapan tersebut diawali dengan menyusun diagram simpal kausal atau Causal Loop Diagram (CLD), dilanjutkan dengan membuat diagram alir atau Stock Flow Diagram (SFD), membuat asumsi-asumsi pada pemodelan tersebut, menampilkan hasil simulasi, melakukan validasi model, melakukan simulasi Business as Usual (BAU) dan diakhiri dengan simulasi skenario ke depan. Seluruh proses dilakukan dengan menggunakan aplikasi Powersim 10.1.

Adapun validasi model akan menggunakan absolute means error (AME), yakni uji pembandingan rata-rata data hasil simulasi terhadap rata-rata data referensi. Data yang digunakan adalah data referensi dan simulasi jumlah penduduk, dengan menggunakan rumus:

$$
M E=\frac{\mid(\text { Rata }- \text { rata Data Hasil Simulasi }- \text { Rata }- \text { rata Data Referensi }) \mid}{\text { Rata }- \text { rata Data Referensi }} \times 100 \%
$$

dengan kriteria toleransi kesalahan maksimum $30 \%$.

\section{Hasil dan Pembahasan}

\section{1. Diagram Simpal Kausal}

Model sistem pengelolaan air yang dibangun dengan sistem simpal kausal atau Causal Loop Diagram (CLD) di Kecamatan Pamulang menggambarkan

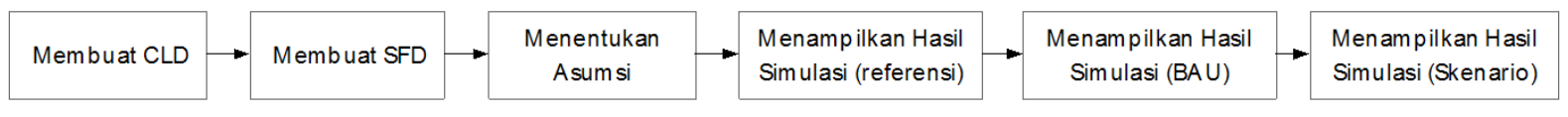

Gambar 1. Bagan tahapan pemodelan dengan system dynamics. 


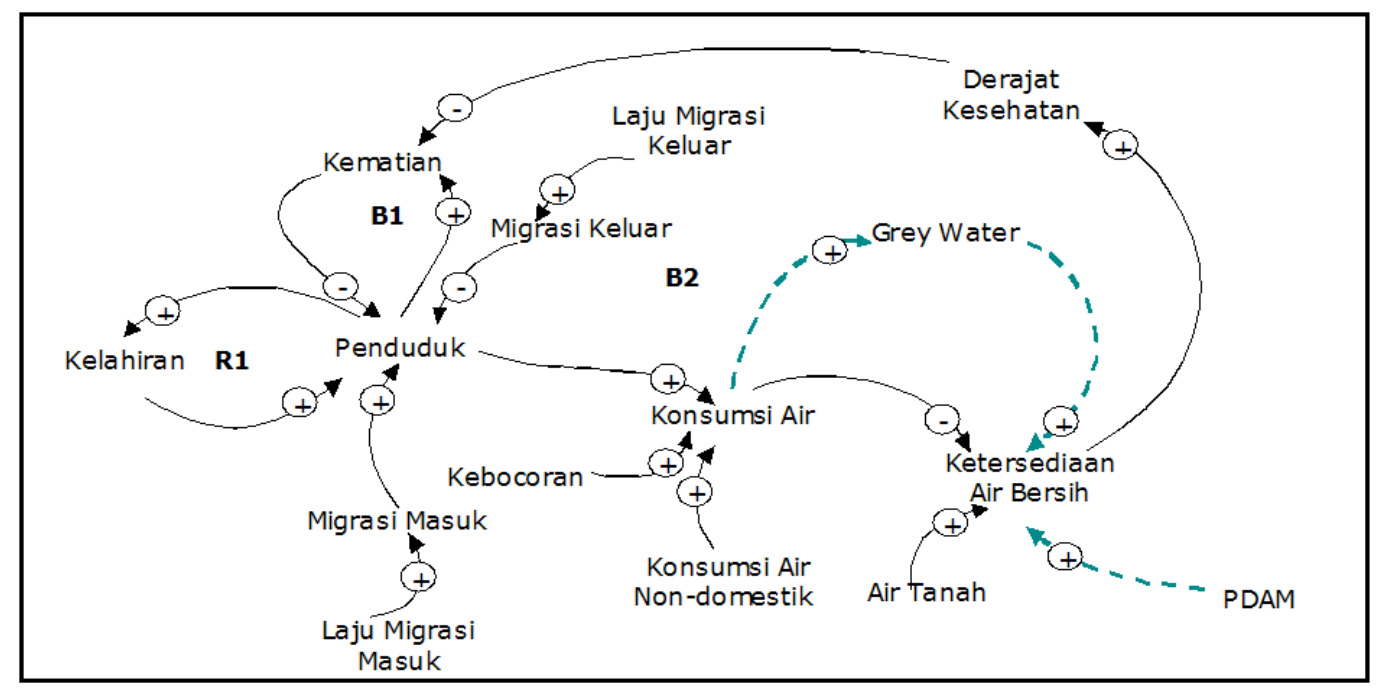

Gambar 2. Diagram Simpal Kausal

sistem hubungan antara variabel penduduk dengan ketersediaan air bersih. Analisis tersebut ditampilkan pada Gambar 2. Secara keseluruhan model simpal kausal terdiri dari 3 lup, yakni 1 lup reinforcing (R) dan 2 lup balancing (B). Antara sub sistem penduduk dan ketersediaan air tergambar secara keseluruhan bersifat reinforcing, artinya apabila salah satu subsistem tidak terkendali, maka akan terjadi umpan balik sebab akibat secara positif (searah), sehingga akan memperkuat seluruh sistem dengan unsurunsur penyusunnya.

Subsistem kependudukan terdiri dari variabel-variabel yang berpengaruh terhadap pertumbuhan penduduk, yakni kelahiran, kematian, migrasi masuk dan migrasi keluar. Pada subsistem ini, terjadi lup balancing, sebagai hasil dari lup R1 dan B1. Pertumbuhan penduduk akan ditingkatkan oleh jumlah kelahiran dan migrasi masuk, dan dikendalikan oleh kematian dan migrasi keluar.

Lup ketiga adalah lup balancing (B2), antara variabel penduduk, dengan konsumsi air, yang berlanjut dengan variabel ketersediaan air, yang kemudian memberikan umpan balik ke subsistem kependudukan melalui variabel derajat kesehatan dan kematian. Ketersediaan air bersih yang meningkat, akan mengakibatkan peningkatan derajat kesehatan, yang terbukti dalam meningkatkan angka harapan hidup dan menurunkan laju kematian.

Variabel PDAM dan grey water merupakan variabel pada simulasi skenario ke depan (ditandai dengan garis biru terputusputus pada CLD). Variabel grey water dipergunakan sebagai variabel simulasi, yang menurut beberapa penelitian (Dinas Tata Kota Bangunan dan Pemukiman Kota Tangerang Selatan, 2014; Ester Suoth, 2018; Hidayat et al., 2019) berpotensi sebagai sumber air baru setelah diolah kembali (recycling). Secara keseluruhan, pengaruh umpan balik tersebut pada hubungan subsistem kependudukan dan ketersediaan air bersifat balancing, yang pada diagram dinotasikan oleh B2.

\section{2. Diagram Alir}

Diagram alir atau Stock Flow Diagram (SFD) dikonstruksi dari diagram simpal kausal, yang menggambarkan hubungan variabel-variabel dalam keseluruhan sistem (Gambar 3). Oleh karena SFD dibangun dari CFD pada bagian 3.1, maka seluruh variabel dalam bagian CFD dipergunakan 


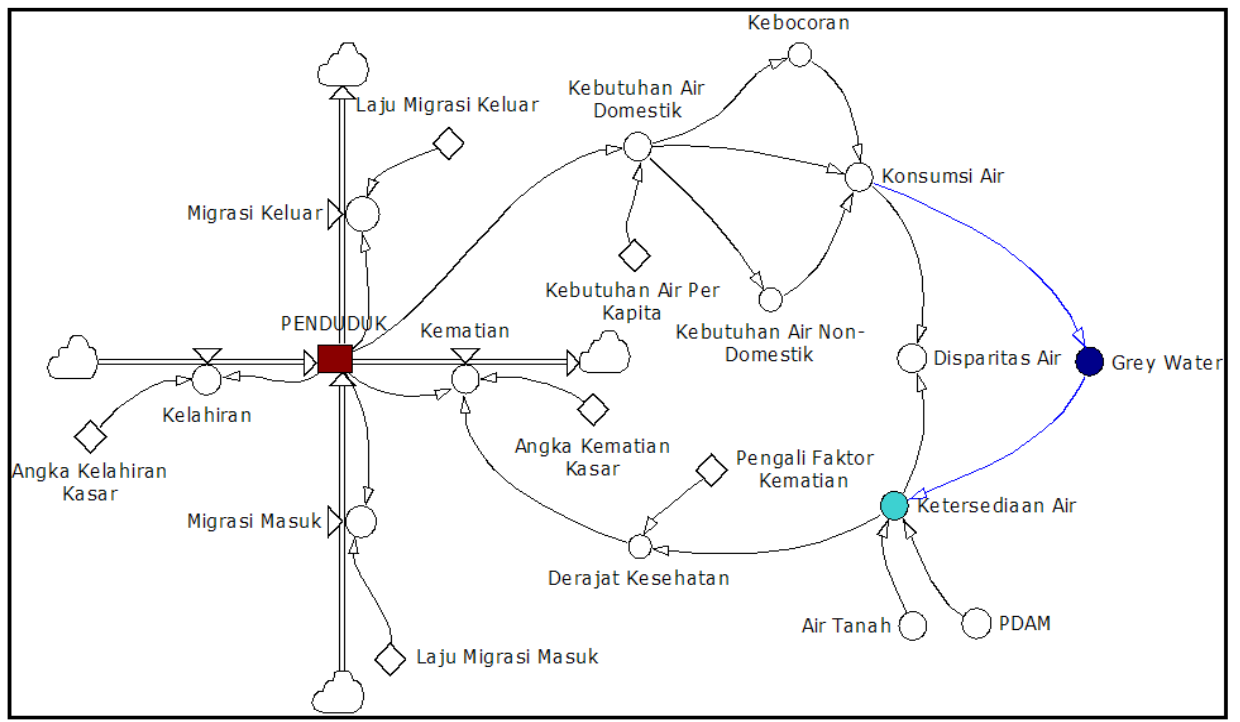

Gambar 3. Diagram Alir

dalam pembuatan SFD, dengan penambahan beberapa variabel lain yang dibutuhkan dalam komputasi.

Untuk subsistem kependudukan, variabel yang dimasukkan dalam SFD adalah variabel jumlah penduduk, yang dipengaruhi oleh kelahiran, kematian, migrasi masuk dan migrasi keluar, ditambah dengan variabel konstanta angka kelahiran kasar, angka kematian kasar, laju migrasi masuk dan laju migrasi keluar. Subsistem ketersediaan air terdiri dari variabel jumlah air tanah dan produksi PDAM, konsumsi air yang dihubungkan oleh variabel kebutuhan air domestik ke subsistem kependudukan. Pada subsistem ini juga terdapat variabel kebocoran air dan kebutuhan air nondomestik yang diperhitungkan dari kebutuhan air domestik dalam sistem, serta variabel derajat kesehatan.

Selain itu terdapat variabel disparitas air, yakni selisih antara kebutuhan dan ketersediaan air, serta jumlah grey water yang merupakan produksi perkiraan dari konsumsi air keseluruhan. Beberapa konstanta yang ditambahkan pada subsistem ini adalah kebutuhan air per kapita, dan pengali faktor kematian, sebagai akibat dari perhitungan pengaruh peningkatan ketersediaan air terhadap derajat kesehatan.

\section{3. Variabel Model}

Dari hasil pembuatan diagram alir, teridentifikasi beberapa variabel dalam pemodelan ini, yang terdiri dari stok (S), flow (F), auxiliary (A), maupun konstanta (C). Definisi variabel tersebut diringkas pada Tabel 2 .

\section{4. Asumsi Model}

Pemodelan menggunakan beberapa asumsi, yang didapatkan dari penelusuran literatur berupa laporan dan hasil penelitian terdahulu, untuk keadaan pada tahun analisis (2014). Asumsi-asumsi tersebut dideskripsikan seperti pada Tabel 3.

\section{5. Hasil Simulasi}

Dari data historis, diperoleh simulasi model dalam bentuk grafik yang ditampilkan pada Gambar 4 dan data pada Tabel 4. Pertumbuhan penduduk Kecamatan Pamulang seperti digambarkan pada Grafik 3a terlihat pada pola pertumbuhan eksponensial, dan pada tahun 2018 (pada tahun terakhir simulasi) mencapai 557.205 jiwa, yang jika dikaitkan dengan penyediaan 
Tabel 2. Variabel Pemodelan

\begin{tabular}{|c|c|c|c|c|c|}
\hline No & Variabel & Definisi & Nilai* & Satuan & Sumber Data \\
\hline 1 & $\begin{array}{l}\text { Angka } \\
\text { kelahiran kasar } \\
\text { (C) }\end{array}$ & $\begin{array}{l}\text { Jumlah kelahiran per } 1000 \\
\text { penduduk }\end{array}$ & 19,4 & $/ 1000$ & $\begin{array}{l}\text { BPS Indonesia, Proyeksi } \\
\text { Penduduk Indonesia 2010- } \\
2035 \text { (Badan Pusat Statistik } \\
\text { Indonesia, 2013)* }\end{array}$ \\
\hline 2 & $\begin{array}{l}\text { Angka } \\
\text { kelahiran (F) }\end{array}$ & $\begin{array}{l}\text { Angka kelahiran kasar } \\
\text { dikalikan jumlah penduduk }\end{array}$ & 6.285 & orang & Hasil perhitungan \\
\hline 3 & $\begin{array}{l}\text { Angka } \\
\text { kematian kasar } \\
\text { (C) }\end{array}$ & $\begin{array}{l}\text { Jumlah kelahiran per } 1000 \\
\text { penduduk }\end{array}$ & 5,70 & $/ 1000$ & $\begin{array}{l}\text { BPS Indonesia, Proyeksi } \\
\text { Penduduk Indonesia 2010- } \\
2035 \text { (Badan Pusat Statistik } \\
\text { Indonesia, 2013)* }\end{array}$ \\
\hline 4 & $\begin{array}{l}\text { Angka } \\
\text { kematian (F) }\end{array}$ & $\begin{array}{l}\text { Angka kematian kasar } \\
\text { dikalikan jumlah penduduk }\end{array}$ & 1.847 & orang & Hasil perhitungan \\
\hline 5 & $\begin{array}{l}\text { Laju migrasi } \\
\text { masuk }(\mathrm{C})\end{array}$ & $\begin{array}{l}\text { Rata-rata pertumbuhan } \\
\text { migrasi masuk }\end{array}$ & 1,96 & & BPS Kota Tangerang Selatan \\
\hline 6 & $\begin{array}{l}\text { Migrasi masuk } \\
\text { (F) }\end{array}$ & $\begin{array}{l}\text { Laju migrasi masuk } \\
\text { dikalikan jumlah penduduk }\end{array}$ & 6.359 & orang & Hasil perhitungan \\
\hline 7 & $\begin{array}{l}\text { Laju migrasi } \\
\text { keluar }(\mathrm{C})\end{array}$ & $\begin{array}{l}\text { Rata-rata pertumbuhan } \\
\text { migrasi keluar }\end{array}$ & 1,16 & & BPS Kota Tangerang Selatan \\
\hline 8 & $\begin{array}{l}\text { Migrasi keluar } \\
(\mathrm{F})\end{array}$ & $\begin{array}{l}\text { Laju migrasi keluar } \\
\text { dikalikan jumlah penduduk }\end{array}$ & 3.756 & orang & Hasil perhitungan \\
\hline 9 & $\begin{array}{l}\text { Jumlah } \\
\text { penduduk (S) }\end{array}$ & Jumlah penduduk & 323.957 & orang & BPS Kota Tangerang Selatan \\
\hline 10 & $\begin{array}{l}\text { Kebutuhan air } \\
\text { domestik (A) }\end{array}$ & $\begin{array}{l}\text { Jumlah kebutuhan air } \\
\text { penduduk (perkalian dari } \\
\text { jumlah penduduk dengan } \\
\text { kebutuhan air per kapita }\end{array}$ & 17.500.157.140 & $\mathrm{L} /$ tahun & $\begin{array}{l}\text { Dinas Tata Kota Bangunan dan } \\
\text { Pemukiman Kota Tangerang } \\
\text { Selatan, } 2014\end{array}$ \\
\hline 11 & $\begin{array}{l}\text { Kebutuhan air } \\
\text { per kapita (C) }\end{array}$ & $\begin{array}{l}\text { Kebutuhan air per orang per } \\
\text { tahun }\end{array}$ & 54.020 & $\mathrm{~L} /$ tahun & \\
\hline 12 & $\begin{array}{l}\text { Kebutuhan air } \\
\text { non domestic } \\
\text { (A) }\end{array}$ & $\begin{array}{l}\text { Kebutuhan air untuk } \\
\text { fasilitas umum yang } \\
\text { diperhitungkan dari } \\
\text { kebutuhan air domestik }\end{array}$ & $20 \%$ & L/tahun & \\
\hline 13 & $\begin{array}{l}\text { Kebutuhan air } \\
\text { untuk antisipasi } \\
\text { kebocoran (A) }\end{array}$ & $\begin{array}{l}\text { Kebutuhan air untuk } \\
\text { fasilitas umum yang } \\
\text { diperhitungkan dari } \\
\text { kebutuhan air domestik }\end{array}$ & $5 \%$ & $\mathrm{~L} /$ tahun & \\
\hline 14 & $\begin{array}{l}\text { Konsumsi air } \\
\text { (A) }\end{array}$ & $\begin{array}{l}\text { Jumlah kebutuhan air } \\
\text { domestik, non domestik dan } \\
\text { kebocoran }\end{array}$ & 21.875 .196 .425 & L/tahun & $\begin{array}{l}\text { Hasil perhitungan } \\
\text { Hasil perhitungan }\end{array}$ \\
\hline 15 & $\begin{array}{l}\text { Disparitas air } \\
\text { (A) }\end{array}$ & $\begin{array}{l}\text { Selisih antara konsumsi air } \\
\text { dengan ketersediaan air }\end{array}$ & 21.033.296.973 & L/tahun & \\
\hline 16 & $\begin{array}{l}\text { Ketersediaan } \\
\text { air (A) }\end{array}$ & Jumlah ketersediaan air & 42.908.493.398 & L/tahun & Hasil perhitungan \\
\hline 17 & Air Tanah (A) & \multicolumn{2}{|c|}{$\begin{array}{l}\text { Jumlah ketersediaan air tanah (debit air } \\
\text { dikalikan dengan fraksi ketersediaan air tanah, } \\
\text { jumlah fasilitas air tanah per penduduk, fraksi } \\
\text { pengambilan air tanah dan nilai maksimum } \\
\text { pengambilan yang diperbolehkan) }\end{array}$} & L/Tahun & $\begin{array}{l}\text { (Dinas Energi dan Sumber } \\
\text { Daya Mineral Provinsi } \\
\text { Banten, 2019): debit air }= \\
\text { 1,2 L/detik/hari; jumlah } \\
\text { fasilitas air }=80 \% \text { dikali } \\
\text { jumlah penduduk, fraksi } \\
\text { pengambilan air tanah, dan } \\
\text { nilai maksimum }=40 \% \text { dari } \\
\text { debit (PP No } 43 / 2008 \text { ) }\end{array}$ \\
\hline 18 & $\begin{array}{l}\text { Koefisien } \\
\text { derajat } \\
\text { kesehatan }(\mathrm{A})\end{array}$ & $\begin{array}{l}\text { Koefisien pengaruh } \\
\text { peningkatan nilai harapan } \\
\text { hidup }\end{array}$ & 0,0002 & & (Kustanto, 2015) \\
\hline
\end{tabular}

Keterangan: * Nilai berdasarkan keadaan pada tahun 2014, dengan sumber data sekunder. 
Tabel 3. Asumsi Pemodelan

\begin{tabular}{lllll}
\hline No & \multicolumn{1}{c}{ Variabel } & Nilai* & Satuan & \multicolumn{1}{c}{ Sumber Data } \\
\hline 1 & $\begin{array}{l}\text { Target pelayanan PDAM untuk seluruh } \\
\text { penduduk }\end{array}$ & 80 & $\%$ & $\begin{array}{l}\text { SDGs (Dinas Tata Kota Bangunan dan } \\
\text { Pemukiman Kota Tangerang Selatan, 2014) } \\
\text { (Dinas Tata Kota Bangunan dan Pemukiman }\end{array}$ \\
2 & $\begin{array}{l}\text { Target debit air PDAM tahap IV } \\
\text { Kota Tangerang Selatan, 2014) } \\
\text { (Ester Suoth, 2018; Hidayat } \text { et al., 2019) }\end{array}$ \\
\hline $\begin{array}{l}\text { Produksi grey water dari pengolahan air } \\
\text { konsumsi }\end{array}$ & 700 & L/det & $\%$ & \\
\hline
\end{tabular}

Keterangan: * Nilai berdasarkan keadaan pada tahun 2014, dengan sumber data sekunder.
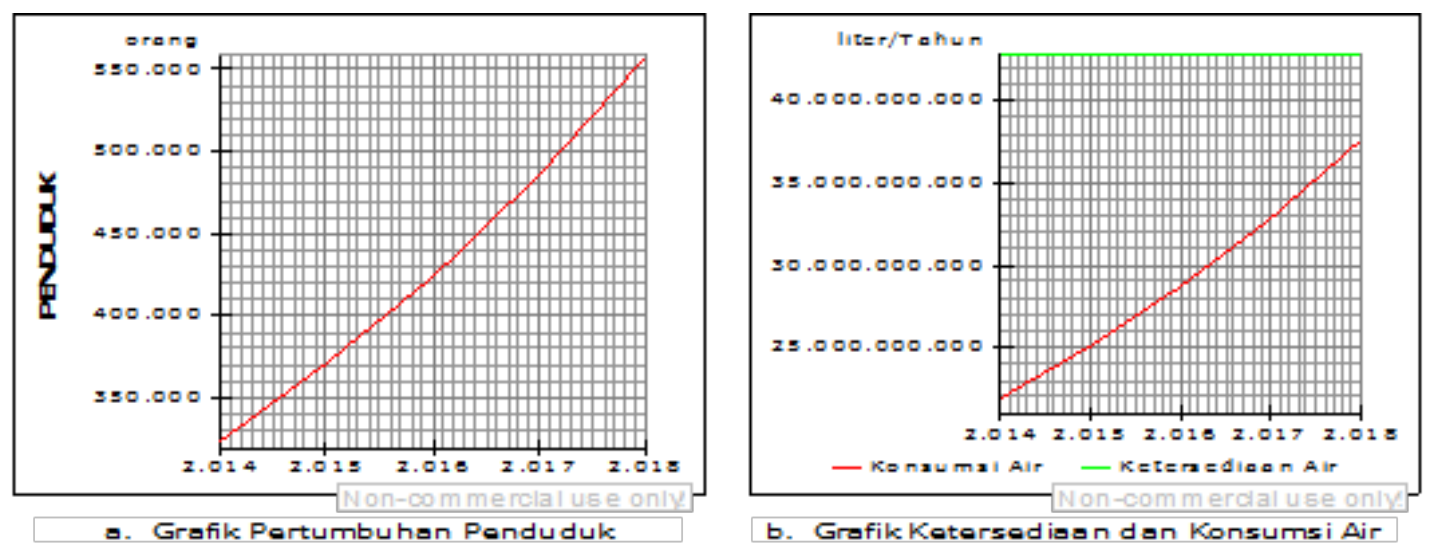

Gambar 4. (a) Grafik Pertumbuhan Penduduk dan (b) Ketersediaan Konsumsi Air Berdasarkan Data Historis.

Tabel 4. Simulasi Penyediaan Air Berdasarkan Data Historis

\begin{tabular}{ccccc}
\hline Tahun & $\begin{array}{c}\text { Penduduk } \\
\text { (orang) }\end{array}$ & $\begin{array}{c}\text { Konsumsi air (liter/ } \\
\text { tahun) }\end{array}$ & $\begin{array}{c}\text { Ketersediaan air (liter/ } \\
\text { tahun) }\end{array}$ & $\begin{array}{c}\text { Disparitas air (liter/ } \\
\text { tahun) }\end{array}$ \\
\hline 2014 & 323.957 & $21.875 .196 .425,00$ & $42.908 .493 .398,00$ & $21.033 .296 .973,00$ \\
2015 & 370.996 & $25.051 .511 .475,72$ & $42.908 .493 .398,00$ & $17.856 .981 .922,28$ \\
2016 & 424.865 & $28.689 .032 .775,98$ & $42.908 .493 .398,00$ & $14.219 .460 .622,02$ \\
2017 & 486.557 & $32.854 .728 .243,42$ & $42.908 .493 .398,00$ & $10.053 .765 .154,58$ \\
2018 & 557.205 & $37.625 .289 .649,09$ & $42.908 .493 .398,00$ & $5.283 .203 .748,91$ \\
\hline
\end{tabular}

Sumber data: hasil simulasi

air, berada pada kategori kota sedang (Susanto, 2011). Pada simulasi ini terlihat bahwa pada tahun awal 2014 ketersediaan air tanah masih mencukupi untuk kebutuhan masyarakat Pamulang, bahkan masih terdapat kelebihan air sebesar 5.283.204 $\mathrm{m}^{3}$ pada tahun 2018, walaupun suplai air hanya dari air tanah saja. Sampai dengan tahun 2017, penyediaan air di Kecamatan
Pamulang hanya melalui sumur gali dan sumur pompa (Rachmawati, 2012). Jumlah kebutuhan air, ketersediaan, dan disparitas selama 5 tahun (2014-2018) ditampilkan pada Tabel 4.

\section{6. Validasi Model}

Validasi model dilakukan dengan menggunakan rumus AME menunjukkan 
bahwa nilai AME adalah sebesar 26,55\% (Tabel 5), sehingga model yang digunakan dalam analisis ini valid.

\section{7. Hasil Simulasi Business as Usual}

Analisis simulasi Business as Usual (BAU) dilakukan dengan tanpa mengubah nilai variabel pada sistem, hanya ditambahkan tahun simulasi, yakni selama periode 5 tahun dari data historis tahun 2018, sehingga periode simulasi menjadi dari tahun 2014 sampai 2023 (10 tahun). Hasil simulasi ditampilkan pada Gambar 5. Secara umum, behavior grafik konsumsi air bersifat continuous growth, sehingga terjadi kekurangan air mulai tahun 2019.

Simulasi konsumsi, ketersediaan dan disparitas air berdasarkan keadaan BAU ditampilkan pada Tabel 6. Dari Tabel 6 terlihat bahwa pada tahun 2019 mulai terjadi kekurangan air sebesar $180.051 \mathrm{~m}^{3} /$ tahun, sedangkan pada tahun 2023 kekurangan sebesar 31.203.708 $\mathrm{m}^{3} /$ tahun. Hal itu terutama disebabkan oleh pertumbuhan penduduk dan pengadaan air bersih yang hanya mengandalkan air tanah.

Walaupun air tanah merupakan sumber air bersih dengan kualitas baik, penyedotan yang berlebihan berisiko untuk menurunkan permukaan tanah (Bakr, 2015), sehingga memerlukan konservasi, baik untuk penghematan (Primadian $\mathrm{N}$ et al., 2016; Taufiq et al., 2018) maupun antisipasi perubahan iklim (Kirono et al., 2014; Máñez et al., 2012). Kekurangan tersebut dicoba diatasi dengan beberapa skenario kebijakan, dengan menggunakan pemodelan.

Tabel 5. Perhitungan Nilai AME

\begin{tabular}{llcc}
\hline \multirow{2}{*}{ No } & \multirow{2}{*}{ Tahun } & \multicolumn{2}{c}{ Jumlah Penduduk (orang) } \\
& & Data Referensi & Data Simulasi \\
\hline 1 & 2014 & 323.951 & 323.957 \\
2 & 2015 & 332.984 & 370.996 \\
3 & 2016 & 341.968 & 424.865 \\
4 & 2017 & 350.923 & 486.557 \\
5 & 2018 & 359.810 & 557.205 \\
\hline Rata-rata & $341.927,20$ & $432.716,00$ \\
Nilai AME & & 26,55 & \\
\hline
\end{tabular}

Sumber data: Hasil simulasi
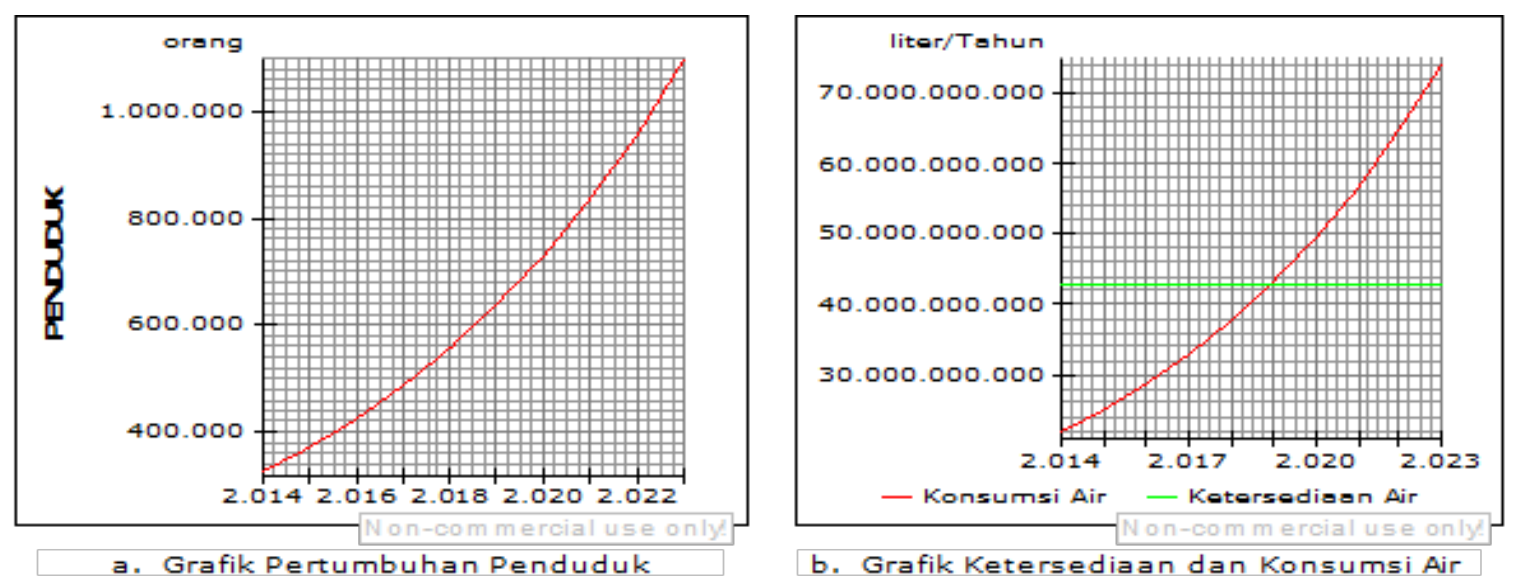

Gambar 5. (a) Grafik Pertumbuhan Penduduk dan (b) Ketersediaan Konsumsi Air Berdasarkan Business as Usual. (Sumber data: Hasil simulasi) 
Tabel 6. Simulasi Penyediaan Air Berdasarkan Simulasi Business As Usual

\begin{tabular}{ccccc}
\hline Tahun & $\begin{array}{c}\text { Penduduk } \\
\text { (orang) }\end{array}$ & $\begin{array}{c}\text { Konsumsi air (liter/ } \\
\text { tahun) }\end{array}$ & $\begin{array}{c}\text { Ketersediaan air (liter/ } \\
\text { tahun) }\end{array}$ & $\begin{array}{c}\text { Disparitas air (liter/ } \\
\text { tahun) }\end{array}$ \\
\hline 2014 & 323.957 & $21.875 .196 .425,00$ & $42.908 .493 .398,00$ & $21.033 .296 .973,00$ \\
2015 & 370.996 & $25.051 .511 .475,72$ & $42.908 .493 .398,00$ & $17.856 .981 .922,28$ \\
2016 & 424.865 & $28.689 .032 .775,98$ & $42.908 .493 .398,00$ & $14.219 .460 .622,02$ \\
2017 & 486.557 & $32.854 .728 .243,42$ & $42.908 .493 .398,00$ & $10.053 .765 .154,58$ \\
2018 & 557.205 & $37.625 .289 .649,09$ & $42.908 .493 .398,00$ & $5.283 .203 .748,91$ \\
2019 & 638.112 & $43.088 .544 .537,33$ & $42.908 .493 .398,00$ & $-180.051 .139,33$ \\
2020 & 730.767 & $49.345 .073 .158,53$ & $42.908 .493 .398,00$ & $-6.436 .579 .760,53$ \\
2021 & 836.876 & $56.510 .060 .183,42$ & $42.908 .493 .398,00$ & $-13.601 .566 .785,42$ \\
2022 & 958.392 & $64.715 .415 .289,27$ & $42.908 .493 .398,00$ & $-21.806 .921 .891,27$ \\
2023 & 1.097 .552 & $74.112 .201 .658,77$ & $42.908 .493 .398,00$ & $-31.203 .708 .260,77$ \\
\hline
\end{tabular}
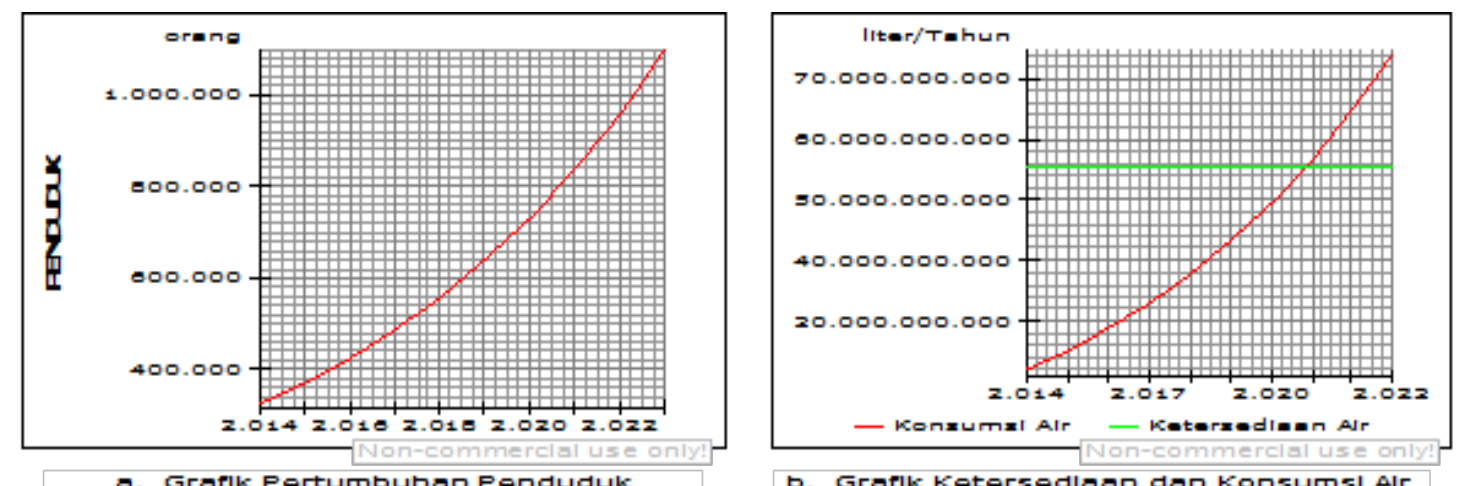

Gambar 6. (a) Grafik Pertumbuhan Penduduk dan (b) Ketersediaan Konsumsi Air Berdasarkan Skenario Pemanfaatan PDAM. (Sumber data: Hasil simulasi)

\section{7. Simulasi Skenario ke Depan}

Pemodelan menyajikan dua skenario ke depan, yakni pertama, adanya penyediaan air oleh PDAM yang dibangun pada tahun 2018. Menurut Dinas Tata Kota Bangunan dan Pemukiman Kota Tangerang Selatan (2014), kapasitas PDAM yang melayani Kecamatan Pamulang akan mencapai 400 L/det, sehingga nilai tersebut dimasukkan ke dalam simulasi. Hasil pemodelan ditampilkan pada Gambar 6 dan Tabel 7.

Dari simulasi dengan menggunakan penyediaan air oleh PDAM, terlihat dari grafik bahwa terdapat pergeseran kurva ketersediaan air menjadi lebih tinggi daripada keadaan BAU, dan kelebihan pasokan air bersih masih terjadi sampai tahun 2020 . Keadaan konsumsi, ketersediaan dan jumlah disparitas air ditampilkan pada Tabel 7. Pada tahun 2018 terjadi peningkatan ketersediaan air bila dibandingkan dengan pada keadaan BAU dan disparitas air masih positif (terjadi kelebihan) sampai dengan tahun 2020. Kekurangan air kembali terjadi pada tahun 2021, sebesar $1.007 .649 \mathrm{~m}^{3}$.

Kekurangan air bersih kemudian diatasi dengan skenario yang kedua, dengan menambahkan variabel pengolahan air bekas pakai (grey water). Pemanfaatan grey water dengan menggunakan teknologi pengeolahan air merupakan potensi besar untuk mendukung sistem pengadaan air yang lestari di perkotaan (Irawan et al., 2014; Kerstens et al., 2015; Silvestre, 2012; Van der Wulp et al., 2016). Penelitian yang dilakukan oleh (Ester Suoth, 2018; Hidayat et al., 2019) 
Tabel 7. Simulasi Penyediaan Air dengan Skenario Pemanfaatan PDAM

\begin{tabular}{ccccc}
\hline Tahun & $\begin{array}{c}\text { Penduduk } \\
\text { (orang) }\end{array}$ & $\begin{array}{c}\text { Konsumsi air (liter/ } \\
\text { tahun) }\end{array}$ & $\begin{array}{c}\text { Ketersediaan air (liter/ } \\
\text { tahun) }\end{array}$ & $\begin{array}{c}\text { Disparitas air (liter/ } \\
\text { tahun) }\end{array}$ \\
\hline 2014 & 323.957 & $21.875 .196 .425,00$ & $55.522 .893 .398,00$ & $33.647 .696 .973,00$ \\
2015 & 371.015 & $25.052 .808 .405,36$ & $55.522 .893 .398,00$ & $30.470 .084 .992,64$ \\
2016 & 424.909 & $28.692 .003 .344,87$ & $55.522 .893 .398,00$ & $26.830 .890 .053,13$ \\
2017 & 486.632 & $32.859 .831 .226,18$ & $55.522 .893 .398,00$ & $22.663 .062 .171,82$ \\
2018 & 557.321 & $37.633 .081 .776,63$ & $55.522 .893 .398,00$ & $17.889 .811 .621,37$ \\
2019 & 638.278 & $43.099 .699 .272,90$ & $55.522 .893 .398,00$ & $12.423 .194 .125,10$ \\
2020 & 730.994 & $49.360 .402 .861,51$ & $55.522 .893 .398,00$ & $6.162 .490 .536,49$ \\
2021 & 837.179 & $56.530 .542 .248,65$ & $55.522 .893 .398,00$ & $-1.007 .648 .850,65$ \\
2022 & 958.789 & $64.742 .222,949,28$ & $55.522 .893 .398,00$ & $-9.219 .329 .551,28$ \\
2023 & 1.098 .064 & $74.146 .740 .251,97$ & $55.522 .893 .398,00$ & $-18.623 .846 .853,97$ \\
\hline
\end{tabular}

Sumber data: Hasil simulasi

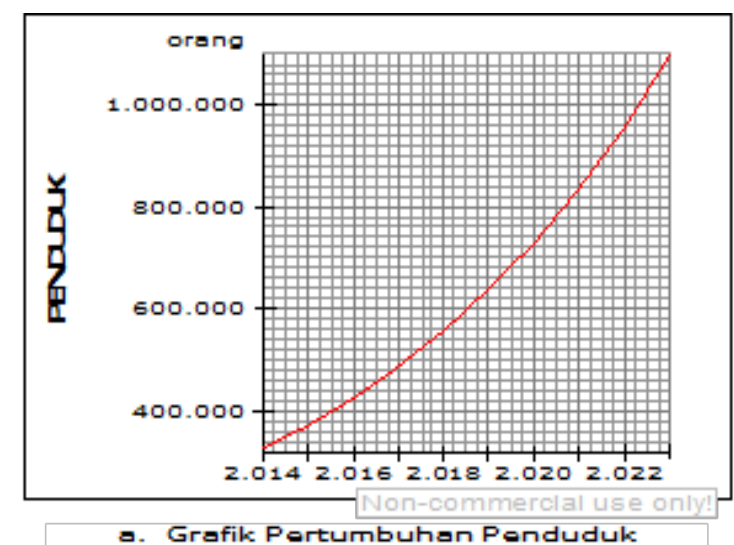

Gambar 7. (a) Grafik Pertumbuhan Penduduk dan (b) Ketersediaan Konsumsi Air Berdasarkan Skenario Pemanfaatan PDAM dan Grey water. (Sumber data: Hasil simulasi)

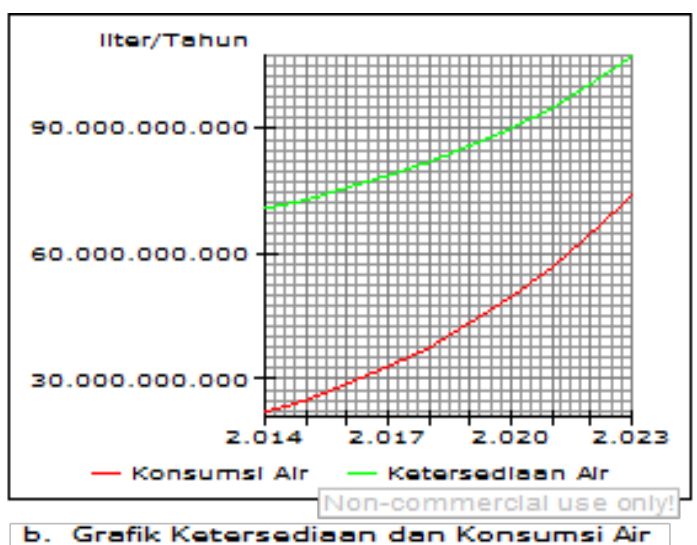

b. Grafik Ketersediaan dan Konsumsi Air di Serpong dan Bogor menunjukkan bahwa masyarakat bersedia menggunakan grey water untuk memenuhi kebutuhan seharihari. Bahkan dengan teknologi yang tepat, grey water dapat ditingkatkan kualitasnya untuk memenuhi baku mutu. Skenario ke masa depan dengan kapasitas moderat, yakni hasil pengolahan grey water dapat mencapai $70 \%$ dari konsumsi. Nilai tersebut kemudian dimasukkan ke dalam model, untuk menambah persediaan air bersih. Hasil simulasi ditampilkan pada Gambar 7.

Pada gambar $7 \mathrm{~b}$ terlihat perubahan grafik penyediaan air, yakni menjadi continuous growth, dengan behavior kurva penyediaan air yang lebih landai daripada kurva konsumsi air. Keadaan tersebut menggambarkan bahwa di awal 
Tabel 8. Simulasi Penyediaan Air dengan Skenario Pemanfaatan PDAM dan Grey water

\begin{tabular}{ccccc}
\hline Tahun & $\begin{array}{c}\text { Penduduk } \\
\text { (orang) }\end{array}$ & $\begin{array}{c}\text { Konsumsi air (liter/ } \\
\text { tahun) }\end{array}$ & $\begin{array}{c}\text { Ketersediaan air (liter/ } \\
\text { tahun) }\end{array}$ & $\begin{array}{c}\text { Disparitas air (liter/ } \\
\text { tahun) }\end{array}$ \\
\hline 2014 & 323.957 & $21.875 .196 .425,00$ & $70.835 .530 .895,50$ & $48.960 .334 .470,50$ \\
2015 & 371.039 & $25.054 .382 .750,04$ & $73.060 .961 .323,03$ & $48.006 .578 .572,99$ \\
2016 & 424.967 & $28.695 .871 .586,05$ & $75.610 .003 .508,24$ & $46.914 .131 .922,18$ \\
2017 & 486.738 & $32.866 .970 .532,30$ & $78.529 .772 .770,61$ & $45.662 .802 .238,31$ \\
2018 & 557.494 & $37.644 .812 .127,41$ & $81.874 .261 .887,19$ & $44.229 .449 .759,78$ \\
2019 & 638.546 & $43.117 .795 .949,55$ & $85.705 .350 .562,69$ & $42.587 .554 .613,13$ \\
2020 & 731.392 & $49.387 .244 .863,58$ & $90.093 .964 .802,51$ & $40.706 .719 .938,93$ \\
2021 & 837.754 & $56.569 .307 .984,49$ & $95.121 .408 .987,14$ & $38.552 .101 .002,65$ \\
2022 & 958.602 & $64.797 .148 .117,96$ & $100.880 .897 .080,57$ & $36.083 .748 .962,61$ \\
2023 & 1.099 .200 & $74.223 .457 .528,89$ & $107.479 .313 .668,22$ & $33.255 .856 .139,33$ \\
\hline
\end{tabular}

Sumber data: Hasil simulasi

Beberapa penelitian menyampaikan bahwa partisipasi swasta dengan mempertimbangkan risiko merupakan modal penting dalam penyediaan air perkotaan, termasuk pengolahan grey water (Fulazzaky, 2014; Sari et al., 2018; Silvestre, 2012; Simbolon, 2017; Wibowo \& Mohamed, 2010; Wirawan et al., 2018). Demikian juga dengan partisipasi masyarakat (Ariyanti et al., 2020; Cunningham et al., 2019; Dos Santos \& Benetti, 2014; Kösters et al., 2020; Ricks, 2016), terutama pada kesediaan menggunakan grey water yang telah diolah, karena menurut beberapa penelitian, keengganan masyarakat untuk menggunakan grey water yang telah diolah sehingga menjadi lebih baik masih tinggi (Zhu and Chang, 2020). Hal ini sesuai dengan beberapa penelitian terdahulu, yakni bahwa pengembangan smart sensitivity city dapat dilakukan dengan mempersiapkan infrastruktur air, yakni penggunaan air tanah alami (dengan sumur dan PDAM), serta re-use sumberdaya grey water baik untuk memenuhi kebutuhan domestik dan non domestic (Susanto, 2011).

\section{Simpulan}

Kompleksitas masalah penyediaan air dapat diselesaikan dengan menggunakan pendekatan model sistematis, yakni system dinamics yang menggabungkan teori dengan komputasi sebagai dasar penyelesaian ilmiah. Pada kasus penyediaan air bersih di Kecamatan Pamulang, pemodelan yang dibangun, menggunakan pemodelan system dynamics terbukti dapat menemukan solusi, dalam hal ini penggunaan sumberdaya air yang sustainable, yakni pemanfaatan air PDAM dan grey water. Skenario tersebut dapat meningkatkan ketersediaan air, bahkan melebihi kebutuhan normal konsumen.

Permasalahan lanjutan yang harus diselesaikan adalah penyiapan sarana pengolahan air grey water. Sarana tersebut harus dapat meningkatkan kualitas air, yang dapat mencapai efektivitas 70\%. Selain itu, perlu sosialisasi kepada masyarakat, karena sebagian masyarakat masih enggan menggunakan kembali grey water untuk memenuhi kebutuhan domestik.

\section{Daftar Pustaka}

Ari, I. R. D., Ogi, K., Matsushima, K., and Kobayashi, K. (2013). Community participation on water management; Case Singosari District, Malang Regency, Indonesia. Procedia Environmental Sciences, 17, 805-813. doi://10.1016/j. proenv.2013.02.098.

Ariyanti, V., Edelenbos, J., and Scholten, P. (2020). Implementing the integrated water resources management approach in a 
volcanic river basin: a case study of Opak Sub-Basin, Indonesia. Area Development and Policy, 00(00), 17. doi://10.1080/237 92949.2020.1726785.

Badan Pusat Statistik Indonesia. (2013). Proyeksi Penduduk Indonesia 2010-2035. In Bps.

Bakr, M. (2015). Influence of groundwater management on land subsidence in deltas: A case study of Jakarta (Indonesia). Water Resources Management, 29(5), 15411555. doi://10.1007/s11269-014-0893-7.

Berhanu, B. M., Blackhurst, M., Kirisits, M. J., Jamarillo, P., and Carlson, D. (2017). Feasibility of water efficiency and reuse technologies as demand-side strategies for urban water management. Journal of Industrial Ecology, 21(2), 320-331. doi://10.1111/jiec.12430.

Cronin, A. A., Odagiri, M., Arsyad, B., Nuryetty, M. T., Amannullah, G., Santoso, H., ... Nasution, N. A. (2017). Piloting water quality testing coupled with a national socioeconomic survey in Yogyakarta province, Indonesia, towards tracking of Sustainable Development Goal 6 . International Journal of Hygiene and Environmental Health, 220(7), 1141-1151. doi://10.1016/j.ijheh.2017.07.001.

Cunningham, I., Willetts, J., Winterford, K., and Foster, T. (2019). Participation and power dynamics between international non-governmental organisations and local partners: A rural water case study in Indonesia. Water Alternatives, 12(3), 953 974.

Dinas Energi dan Sumber Daya Mineral Provinsi Banten. (2019). Air tanah kota Tangerang Selatan (p. 36). p. 36.

Dinas Tata Kota Bangunan dan Pemukiman Kota Tangerang Selatan. (2014). Laporan akhir pekerjaan penyusunan perencanaan study kelayakan pengembangan sistem penyediaan air minum (SPAM) Zona-3 Kota Tangerang Selatan (p. 280). p. 280. Bandung.

Dos Santos, D. C., and Benetti, A. (2014). Application of the urban water use model for urban water use management purposes. Water Science and Technology, 70(3), 407413. doi://10.2166/wst.2014.229.
Ester Suoth, A. (2018). Pola konsumsi air pada perumahan teratur: studi kasus konsumsi air di perumahan griya Serpong Tangerang Selatan. Jurnal Ecolab, 12(2), 62-70. doi://10.20886/jklh.2018.12.2.62-70.

Fuchs, S., Silva, A., Anggraini, A. K., and Mahdariza, F. (2015). Planning and installation of a drinking water treatment in Gunungkidul, Java, Indonesia. Water Science and Technology: Water Supply, 15(1), 42-49. doi://10.2166/ws.2014.080.

Fulazzaky, M. A. (2014). Challenges of integrated water resources management in Indonesia. Water (Switzerland), 6(7), 2000-2020. doi://10.3390/w6072000.

Hassanzadeh, E., Strickert, G., Morales-Marin, L., Noble, B., Baulch, H., ShupenaSoulodre, E., and Lindenschmidt, K. E. (2019). A framework for engaging stakeholders in water quality modeling and management: Application to the Qu'Appelle River Basin, Canada. Journal of Environmental Management, 231(August 2018), 1117-1126. doi://10.1016/j. jenvman.2018.11.016.

Hidayat, M. Y., Fauzi, R., Harianja, A. H., and Saragih, G. S. (2019). Efisiensi penggunaan grey water dan air hujan dalam rangka menurunkan tingkat penggunaan air baku. Jurnal Teknologi Lingkungan, 20(2), 215. doi://10.29122/jtl.v20i2.3347.

Irawan, D. E., Silaen, H., Sumintadireja, P., Lubis, R. F., Brahmantyo, B., and Puradimaja, D. J. (2014). Groundwatersurface water interactions of Ciliwung River streams, segment Bogor-Jakarta, Indonesia. Environmental Earth Sciences, 73(3), 1295-1302. doi://10.1007/s12665014-3482-4.

Kerstens, S. M., Leusbrock, I., and Zeeman, G. (2015). Feasibility analysis of wastewater and solid waste systems for application in Indonesia. Science of the Total Environment, 530-531, 53-65. doi://10.1016/j.scitotenv.2015.05.077.

Kirono, D. G. C., Larson, S., Tjandraatmadja, G., Leitch, A., Neumann, L., Maheepala, S., ... Selintung, M. (2014). Adapting to climate change through urban water management: A participatory case study in Indonesia. 
Regional Environmental Change, 14(1), 355-367. doi://10.1007/s10113-013-04983.

Kösters, M., Bichai, F., and Schwartz, K. (2020). Institutional inertia: challenges in urban water management on the path towards a water-sensitive Surabaya, Indonesia. International Journal of Water Resources Development, 36(1), 50-68. doi://10.1080 /07900627.2019.1662378.

Kustanto, D. N. (2015). The impact of drinking water acces and sanitation to walfare improvement. Jurnal Sosek Pekerjaan Umum, 7(3), 173-180.

Liu, H., Benoit, G., Liu, T., Liu, Y., and Guo, H. (2015). An integrated system dynamics model developed for managing lake water quality at the watershed scale. Journal of Environmental Management, 155, 11-23. doi://10.1016/j.jenvman.2015.02.046.

Lukman, L., Hidayat, H., Subehi, L., Dina, R., Mayasari, N., Melati, I., ... Ardianto, D. (2019). Pollution loads and its impact on Lake Toba. IOP Conference Series: Earth and Environmental Science, 299(1). doi://10.1088/1755-1315/299/1/012051.

Luo, P., Kang, S., Apip, Zhou, M., Lyu, J., Aisyah, S., ... Nover, D. (2019). Water quality trend assessment in Jakarta: A rapidly growing Asian megacity. PLoS ONE, 14(7), 17.

Máñez, K. S., Husain, S., Ferse, S. C. A., and Costa, M. M. (2012). Water scarcity in the Spermonde Archipelago, Sulawesi, Indonesia: Past, present and future. Environmental Science and Policy, 23, 74 84. doi://10.1016/j.envsci.2012.07.004.

Nohong, M. (2018). The moderating effect of efficiency and non-market capability in relationship between government involvement and resources to performance of water supply companies (PDAM) in Sulawesi, Indonesia. International Journal of Law and Management, 60(2), 402-412. doi://10.1108/IJLMA-11-2016-0117.

Nozari, H., and Liaghat, A. (2014). Simulation of drainage water quantity and quality using system dynamics. Journal of Irrigation and Drainage Engineering, 140(11), 1-9. doi://10.1061/(ASCE)IR.1943-
4774.0000748

Primadian N, D., Lantara, D., Malik, R., and Nur, T. (2016). Pengembangan model sistem dinamik terhadap ketersediaan air bersih di Kabupaten Kutai Timur Provinsi Kalimantan Timur. Journal of Industrial Engineering Management, 1(2), 16-20.

Rachmawati, N. (2012). Sebaran ketersediaan sarana prasarana air di kota Tangerang Selatan. Jurnal Tata Kota dan Daerah, 4, 111-118.

Rasekh, A., and Brumbelow, K. (2015). A dynamic simulation-optimization model for adaptive management of urban water distribution system contamination threats. Applied Soft Computing Journal, 32, 5971. doi://10.1016/j.asoc.2015.03.021.

Rasulung, R., Nawawi, J., and Dirawan, G. D. (2017). Management of water resources and their utilization: Evidence from Indonesia. International Journal of Economic Perspectives, 11(3), 1112-1117.

Ricks, J. I. (2016). Building participatory organizations for common pool resource management: Water user group promotion in Indonesia. World Development, 77, 3447. doi://10.1016/j.worlddev.2015.08.014.

Sari, S. Y. I., Sunjaya, D. K., Shimizu-Furusawa, H., Watanabe, C., and Raksanagara, A. S. (2018). Water sources quality in urban slum settlementalong the contaminatedriverbasin in Indonesia: Application of quantitative microbial risk assessment. Journal of Environmental and Public Health, 2018, 7. doi://10.1155/2018/3806537.

Sesestyo, B., and Laxmi, G. F. (2017). Model dinamis pengelolaan air bersih terpadu di Kota Bogor. Jurnal Kreatif, 5(1), 35-47.

Silvestre, H. C. (2012). Public-private partnership and corporate public sector organizations: Alternative ways to increase social performance in the Portuguese water sector? Utilities Policy, 22, 41-49. doi://10.1016/j.jup.2012.01.002.

Simbolon, J. (2017). Critical systems thinking review on decentralized drinking water management in Nauli City, Indonesia. Systems Research and Behavioral Science, 34(5), 643-653. doi://10.1002/sres.2490.

Sun, Y., Liu, N., Shang, J., and Zhang, J. (2017). 
Sustainable utilization of water resources in China: A system dynamics model. Journal of Cleaner Production, 142, 613625. doi://10.1016/j.jclepro.2016.07.110.

Susanto, A. (2011). Model dinamik penyediaan air baku melalui pendekatan water sensitive city di das ciliwung hulu (kasus desa bendungan, kecamatan Ciawi, Kabupaten Bogor). 1-13.

Taufiq, A., Hosono, T., Ide, K., Kagabu, M., Iskandar, I., Effendi, A. J., ... Shimada, J. (2018). Impact of excessive groundwater pumping on rejuvenation processes in the Bandung basin (Indonesia) as determined by hydrogeochemistry and modeling. Hydrogeology Journal, 26(4), 1281-1284. doi://10.1007/s10040-018-1728-z.

Tian, Y., Li, C., Yi, Y., Wang, X., and Shu, A. (2020). Dynamic model of a sustainable water resources utilization system with coupled water quality and quantity in Tianjin city. Sustainability (Switzerland), 12(10). doi://10.3390/su12104254.

Van der Wulp, S. A., Dsikowitzky, L., Hesse, K. J., and Schwarzbauer, J. (2016). Master Plan Jakarta, Indonesia: The giant seawall and the need for structural treatment of municipal waste water. Marine Pollution Bulletin, 110(2), 686-693. doi://10.1016/j. marpolbul.2016.05.048.

Wang, G., Wang, S., Kang, Q., Duan, H., and Wang, X. (2016). An integrated model for simulating and diagnosing the water quality based on the system dynamics and Bayesian network. Water Science and Technology, 74(11), 2639-2655. doi://10.2166/wst.2016.442.
Wei, T., Lou, I., Yang, Z., and Li, Y. (2016). A system dynamics urban water management model for Macau, China. Journal of Environmental Sciences (China), 50, 117126. doi://10.1016/j.jes.2016.06.034

Wibowo, A., and Alfen, H. W. (2015). Predicting the probability of default for municipal water utilities in Indonesia. Public Works Management and Policy, 20(4), 337-359. doi://10.1177/1087724X14558269.

Wibowo, A., and Mohamed, S. (2010). Risk criticality and allocation in privatised water supply projects in Indonesia. International Journal of Project Management, 28(5), 504-513. doi://10.1016/j. ijproman.2009.08.003.

Wirawan, S. M. S., Maarif, M. S., Riani, E., and Anwar, S. (2018). An evaluation of the sustainability of domestic wastewater management in DKI Jakarta, Indonesia. Advances in Environmental Sciences, 10(3), 147-159. Retrieved from https://search.proquest.com/ docview/2162695192?accountid=17242.

Zhu, D., and Chang, Y. J. (2020). Urban water security assessment in the context of sustainability and urban water management transitions: An empirical study in Shanghai. Journal of Cleaner Production, 275, 13. doi://10.1016/j.jclepro.2020.122968. 